\title{
The Symmetric and Asymmetric impact of FDI Inflows, Economic growth, and Capital Investment on CO2 Emission in Oman-Evidence from ARDL and NARDL Approach
}

\section{Ishfaq Hamid}

Shri Mata Vaishno Devi University

Md Shabbir Alam ( $\square$ shabbir.alam28@gmail.com )

University of Bahrain College of Business Administration https://orcid.org/0000-0002-5001-4553

Muntasir Murshed

North South University

Pabitra Kumar Jena

Shri Mata Vaishno Devi University

Nadia Sha

Dhofar University College of Commerce and Business Administration

Mohammed Noor Alam

University of Bahrain College of Business Administration

\section{Research Article}

Keywords: FDI Inflows, CO2 emissions, Linear and Nonlinear ARDL, Oman

Posted Date: September 7th, 2021

DOI: https://doi.org/10.21203/rs.3.rs-788348/v1

License: (c) (1) This work is licensed under a Creative Commons Attribution 4.0 International License.

Read Full License 


\title{
The Symmetric and Asymmetric impact of FDI Inflows, Economic growth, and Capital Investment on CO2 Emission in Oman-Evidence from ARDL and NARDL Approach
}

\author{
1.Ishfaq Hamid \\ ICSSR Doctoral Fellow, School of Economics, Shri Mata Vaishno Devi University, Katra, Jammu and \\ Kashmir, India. E-mail: bhatishfaq260@gmail.com \\ 2. Md Shabbir Alam \\ Department of Finance and Economics, College of Business Administration, University of Bahrain, P.O. \\ Box- 32038, Zallaq, kingdom of Bahrain, E-mail: shabbir.alam28@gmail.com \\ 3. Muntasir Murshed \\ School of Business and Economics, North South University, Dhaka-1229, Bangladesh \\ E-mail: muntasir.murshed@ northsouth.edu \\ 4. Dr. Pabitra Kumar Jena \\ School of Economics, Shri Mata Vaishno Devi University, Katra, Jammu and Kashmir, India \\ E-mail: pabitrakumarjena@gmail.com

\section{Nadia Sha} \\ Department of Finance and economics, College of Business Administration, Dhofar University, Oman, \\ Email: nsha@du.edu.om

\section{Mohammed Noor Alam} \\ Department of Accounting, College of Business Administration, University of Bahrain, P.O. Box- 32038, \\ Zallaq, kingdom of Bahrain, Email: mohammed8668@gmail.com
}

\begin{abstract}
This study examines the symmetric and asymmetric nexus between capital investment, economic growth, foreign direct investment, and $\mathrm{CO}_{2}$ emissions in Oman during 1980- 2019. For this purpose, we applied ARDL Model for linear cointegration and NARDL model for nonlinear cointegration between capital investment, economic growth, foreign direct investment, and $\mathrm{CO}_{2}$ emissions. The bound test shows the long-term equilibrium relationship among $\mathrm{CO}_{2}$ emissions, capital investment, economic growth, and FDI in both models. The error correction mechanism demonstrates that $\mathrm{CO}_{2}$ emissions congregate to their long-run equilibrium level at a 50.1 percent annual pace of adjustment by integrating capital investment, economic growth, and FDI under the symmetric model. The causality test results show that carbon emissions and FDI, economic growth, and $\mathrm{CO}_{2}$ emissions exhibit bidirectional causal links. While, on the other hand, unidirectional causal links are running from capital investment to GDP. The asymmetric results show that positive shocks to FDI and economic growth have significant tumbling consequences on Oman's carbon dioxide emissions.

In contrast, negative shocks in FDI and economic growth substantially increase carbon dioxide emissions. The research findings also reveal that carbon dioxide emissions are more resilient to negative shocks in FDI and economic growth. Based on these results, this study accomplishes that abatement measures should consist of strategies to enhance the deepness of FDI and economic growth in the Oman economy.
\end{abstract}

Keywords: FDI Inflows, $\mathrm{CO}_{2}$ emissions, Linear and Nonlinear ARDL, Oman JEL Classification: F21, Q56, C22 


\section{Introduction}

2 In present times, one of the utmost challenges faced worldwide is global warming and climate 3 change. These challenges have become the most critical global issues in the face of the survival of

4 humanity from the last several decades. Furthermore, no countries in the world are untouched by 5 this issue, and the outcomes of global warming and climate change can have catastrophic effects 6 on civilization as a whole and carbon dioxide $\left(\mathrm{CO}_{2}\right)$ emissions contributing as the major source of 7 this global issue. Therefore, there is a need for sustainable development that could lead to the 8 reduction of global warming. Ultimately these issues provide an opportunity to the academician, 9 researchers, and decision-makers to provide attention and careful study on the drivers of $\mathrm{CO}_{2}$ 10 emission for developing countries and chalk out the measures and policies to achieve sustainable development and improving the standard of environmental quality (Stern, 2015).

12 The Sultanate of Oman has significantly modified its attitude toward foreign investment since the 13 early 1990s and has devised a new policy to attract Foreign Direct Investment (FDI) based on four essential elements. These include creating a new regulatory precedent, making it easier for foreign investors to do business, liberalizing the economy, and presenting the country as an excellent place to invest (Al. Azri,2016). However, FDI plays an important role in the economic development of developing countries and capital financing that contributes to developing countries in enhancing their productivity through capital, skills, technology transfer, market access, and export promotion. FDI also generates employment opportunities and stimulates business and competition, which are treated as a key instrument for the swift development of these countries (Malampally and Soviet 1999); Heimes and Lensnic 2003; Beton and that. 2009; Reiter \& Stensma 2010; Fernandes and Ponof 2012; Lee 2013).

According to the perception of Environmental Kuznets Curve (EKC), economic development and environmental pollution are related to $\mathrm{N}$-shape. This means that pollution levels rise during the initial period of economic development and then descend as the economy develops and thrives (Ozturk and Acaravci 2010). The environmental Kuznets curve hypothesis further has been intensively investigated and evaluated in the provided literature of energy economics over the last decade to trace a link between the country's economic growth and environmental pollution (e.g., Alam et al., 2011). However, there is a paucity of research on EKC assessment for countries that have a different segment like global trade, capital investment, financial development, and foreign investment inclusive of FDI. 
1 Foreign direct investment can affect the $\mathrm{CO}_{2}$ emission that ultimately leads to environmental 2 degradation. There are contradictory discussions between the researchers; some advocate that FDI provides efficient technology for products that contribute to reducing the air pollution of the country (Stretesky and Lynch 2009; Pao and Tsai,2011; Wu and Liang 2016) advocate that FDI could be treated as the contributor of the air pollution in the country. The logic behind this argument is that FDI strengthens economic growth by increasing productivity which ultimately increases the country's energy consumption. Moreover, high energy consumption usage ultimately 8 led to more $\mathrm{CO}_{2}$ emissions and environmental pollution (Malik and Lan,2016; Shan et al.,2017). Furthermore, polluting firms may decide to put resources into developing countries with fewer environmental laws to reduce production costs, which also indicates an expansion of the country's energy use limit (Acharya 2009); Lau, Chong, and England 2014; Hamid et al., 2020).

Consequently, lax environmental guidelines that permit firms to upsurge their degree of $\mathrm{CO}_{2}$ emissions may entice foreign investors, increasing FDI inflow. The pollution haven hypothesis formalizes this relationship. Given the importance of FDI impact on capital investment, $\mathrm{CO} 2$ emissions, and economic growth, the impetus behind this investigation is to observe the longstanding balanced relationship between investment, economic growth, $\mathrm{CO} 2$ and FDI in Oman, which is an energy-subordinate arising economy.

The carbon emission in Oman is rising from 7.3 million tonnes to 92.8 million tonnes from 1970 to 2019. The emission is growing at an average rate of $8.3 \%$ in Oman (Climate performance index 2021). The recent German watch report (2021) based on 2000 to 2019 data ranks Oman 95th of 180 countries in terms of global climate risk index, collected worldwide; it criticizes the government for failing to implement national environmental policies. Conversely, Oman has been a preferred FDI destination since 2008, inferable from its monetary steadiness and high profit rates when contrasted with many developing nations. Thus, more FDI could drive up energy utilization by boosting the Oman economy's development rate and accordingly add to $\mathrm{CO}_{2}$ emissions. As a result of these factors, Oman offers a fascinating contextual analysis for looking at the connections between $\mathrm{CO} 2$ emissions, capital speculation, economic growth, and FDI inflows, just as tending to effective public environment strategy.

To the best of our knowledge, no research study has looked into the symmetric and asymmetric impact of FDI inflows, capital investment, and economic growth on $\mathrm{CO}_{2}$ emissions in Oman. In 
order to fill this gap, this study uses advanced econometric approaches to examine the impact of

2 economic growth, FDI inflows, and capital investment on $\mathrm{CO}_{2}$ emissions. To begin, the symmetric short-run and long-run relationship between study variables were investigated using the linear ARDL (Autoregressive Distributed Lag). In contrast, the nonlinear ARDL (NARDL) of Shin et al. (2014) is applied to investigate this relationship asymmetrically, to analyze the implications of both positive and negative changes in FDI inflows, economic growth and capital investment on Oman's $\mathrm{CO}_{2}$ emissions. Finally, we used the block exogeneity Wald test to examine the combined

8 (long and short-run) direction of causality between carbon emissions and their determinants. The rest of the research is structured as follows: The second section presents a review of literature. The third section discusses the model and methodology. Section four provides the estimated results and discussion part, and the last section concludes and provides some policy recommendations.

\section{Literature Review}

There is a large corpus of literature on carbon emissions and their determinants. We focus on some recent studies published since 2000 on CO2 emissions, FDI, capital investment, and economic growth.

Keller and Levinson (2000) investigate the impact of varying environmental rules on global investment patterns. The contribution of this study in three ways. Firstly, to avoid making country comparisons, we will start with FDI into the U.S. and the cost of pollution abatement in different states. This is because the data on environmental costs in the United States is higher comparable than that of other countries, and the parameters that measure the conditions in the United States are more similar in some difficulty. Second, we consider disparities in state industrial alignments, identified as an issue in the past. Third, we use a panel of relative abatement costs spanning 18 years, allowing us to account for unobserved state features. This study's findings show that the cost of pollution has had a mild deterrent effect on international business. Irandoust (2001) explores the impact of FDI on GDP and productivity growth expansion in the recipient country. A Vector Autoregressive (VAR) model applies to Denmark, Finland, Norway and Sweden to explore the FDI-led development hypothesis. Based on the new Granger noncausality technique established by Toda and Yamamoto (1995) and Yamada and Toda (1998), the findings demonstrate that FDI and GDP in Norway and Sweden are causally associated in the long 
Norway, with higher FDI leading to economic growth. For Finland and Denmark, our findings

2 did not support the causation link. Two policy implications emerge from the proven bi-directional causation between variables. First, recipient countries can stimulate FDI inflows by boosting economic growth. Second, FDI has a significant impact on economic growth.

5 Xing and Kolstad (2002) demonstrate the validity of theoretical predictions and present a statistical examination of the impact of environmental legislation on the capital flow of polluting enterprises. The study looks at FDI in a spectrum of U.S. industries, including businesses that spend much money on pollution control are listed and businesses with lower pollution control costs. Weak environmental regulation has a negative influence on FDI. We propose two equations, one for FDI assessment and one for pollution emissions, a variable significantly connected with the unobserved variable because laxity is not immediately observable. As a pollutant, we use total national sulfur emissions. The statistical results reveal that the laxity of environmental restrictions in a host nation is a significant factor of FDI from the U.S. for substantially polluting businesses but is inconsequential for less polluting industries when using instruments for the unobserved variable. Jong Choe (2003) uses a panel VAR model to find a causal association between FDI and economic growth and GDI in 80 countries from 1971 to 1995. The results mean that FDI Granger causes economic growth and vice versa; however, when FDI causes growth FDI instead of growth, its impact is more pronounced. Furthermore, GDI does not create economic growth; instead, economic growth causes GDP. These results show that strong positive links between economic growth and FDI inflow or GDI rates do not always mean that large FDI inflows or GDI rates mean rapid economic expansion.

Martínez-Zarzoso, I., and Bengochea-Morancho, A., (2004) investigate the existence of the

23 Environmental Kuznets Curve for $\mathrm{CO}_{2}$ in 22 OECD countries by using Pooled Mean Group Estimator. The data covered from 1975 to 1998. The countries were selected based on quantified emission limitations in the Kyoto Protocols. Results found that N-shaped EKC's existence means that the Original EKC will not stand in the long run; instead, increasing the income level will lead to a positive relationship between economic growth and environmental degradation.

Kholer (2005) investigated the relationship between energy consumption, income, foreign trade, and $\mathrm{CO} 2$ emission in France. This study applied the Johansen cointegration test and Vector Error 
relationship between pollutant emission and energy consumption in France during the period 1960-

2 2000. Further, the result indicates that more usage for energy will be the reason for more Carbon emission, and also, the relationship between output and Carbon emission has a long-run relationship. Finally, the study concludes that output growth causes $\mathrm{CO} 2$ emission and energy consumption in the long run. Apergis et al. (2006) examine the dynamic relationship between FDI inflow and domestic investment. This study uses panel cointegration and causality techniques. Based on the findings, they found a bi-directional relationship between FDI inflow and domestic investment. While on the other hand, the bivariate model assumption found a positive long-run relationship, and the same result happened regarding the countries that have to employ the multivariate model. Furthermore, the study concludes that FDI inflows increase the domestic investment benefits. Changwen and Jiang (2007) looked at how FDI interacts with economic growth in the host country. Toda and Phillips pioneered the vector autoregression (VAR) methodology, which we employ to investigate the causation between FDI and growth in China. The empirical findings show that the two-way causation between FDI and growth is not very strong in China. The fact that China's economic growth draws FDI backs up the market-size argument; nonetheless, while FDI entry boosts China's economic growth to some extent. Ndikumana and Verick (2008) investigate the two-way linkage between FDI and domestic investment in Sub-Saharan Africa. The data analysis found that FDI crowds domestic investment and private investment are drivers of FDI and further explains that improving the domestic climate will attract more FDI. This study illustrates that FDI enhances capital accumulation; thus, the countries can positively impact growth and say that private investment significantly influences FDI. Based on the findings, the study suggests that framing the right policy at the macro and sectoral levels will benefit African countries' growth. Acharyya, J., (2009) examines the GDP growth and environmental degradation in the framework of FDI in the Indian context. Based on the cointegration analysis, the study found that FDI inflow in India has a significantly positive impact on GDP growth in the long run. On the other hand, the author argues that the pollution haven hypothesis is not applicable in 1990 because the FDI inflow positively impacts carbon emission through output growth. However, the scenario changed in the long run, and the government should consider the hypothesis and eliminate the chances of proving the hypothesis. 
Apergis and Payne (2010) examine the casual relationship between Carbon emission, energy consumption, and actual output among eleven countries of the Commonwealth of Independent States. In this study, the panel vector error correction model is used to analyze the data covered from 1992 to 2004. The study found that energy consumption has a positive impact on carbon emission in the long run, but in the EKC hypothesis, it was U-shaped. In the short-run effect, unidirectional causality between energy consumption and actual output is found. This study concludes that efficient energy conservation policies will reduce carbon emissions and enhance

8 the production and consumption of energy. Apargis et al. (2011) carried out a study based on the environmental sustainability approach and tried to explore the link between economic growth and pressure on nature. The study was gone through a panel comprised of 213 countries and spans between 1970 to 2008. The study mainly investigates the effects and pressures on nature due to economic growth, i.e. fixed impact and definite impact-making variable (IV) regressions. The result and discussion find a positive relationship between income and pressure on nature in a cross-country analysis. At the same time, the effect is much more robust in middle-income countries than the low-income countries and does not support the Environmental Kuznets Curve (EKC). Danja (2012) scrutinizes the applicability of FDI and its Impact on the Nigerian Economy. The theoretical evidence of the study indicates that Multinational corporations are highly adaptive to the FDI but on the other hand policy choice of the host country influences the FDI. The study applied both econometrics and statistical method to evaluate the relationship between FDI and major economic indicators. The results find a positive association between FDI and GDP, GFCF, and IIP, but on the other hand, the FDI has not given many contributions to the development of the Nigerian economy. Based on the study conclusion, the researcher finds that FDI flow depends on the policy framework and other factors such as strategic plans, better infrastructure facilities, increasing labor skills, and capacity building. Alkhathlan \& Javid (2013) examined the interrelation between the different parameters such as the country's economic growth, carbon emissions, and energy consumption for this study at the holistic and at a contrasting extent. The study applied standard log-linear functional to inspect the association among the different factors such as carbon emission per capita, total energy consumption per capita, and real GDP per capita. The empirical findings indicate that any changes in per capita income and energy consumption will affect the long-term equilibrium and is rectified 
by a counterbalancing of carbon emission, which means that energy consumption ultimately leads

2 the country's economic growth in the long run. However, there is no causal relationship in the short run. Overall, the study concludes that aggregate and disaggregate energy consumption could be a major source in contributing towards rising carbon emissions in the country. Hence the government should take necessary actions in their policy framework.

Belloumi (2014) studied the relationship between FDI, trade, and economic development in

7 Tunisia. ARDL model was used to analyze the data period from 1970 to 2008 . The study's outcome finds a cointegration among trade, FDI, and economic growth. Furthermore, in the short run, the study explains that there is no significant Granger causality from FDI to economic growth and vice versa. Finally, the study pinpointed the importance of trade openness and economic growth because these two factors attract more FDI, and FDI positively impacts the country's economic 12 growth.

13 Neequaye and Oladi (2015) selected some emerging countries by using a panel approach to evaluates the impact of foreign direct investment inflows and ecological aid spending on environmental deterioration. According to our findings based on a fixed-effects model, environmental Kuznets curve for $\mathrm{CO} 2$ and total greenhouse gas emissions from the energy and manufacturing sectors; however, nitrous oxide emissions from the waste industry and overall greenhouse gas emissions are not included. We also find a clue of a technique impact, which we analyze further by examining capital and labor responses to FDI in various developing nations. Zhang and Zhou (2016) used province panel data from 1995 to 2010 to assess the impact of FDI on China's CO2 emissions at the national and provincial levels. This study uses Stochastic Impacts by Regression on Population. According to the findings, FDI helps China in reducing CO2 emissions. $\mathrm{CO} 2$ emissions are lowered when foreign direct investment (FDI) flows from the west to the east and central regions. Our findings are back to the pollution halo idea, which claims that multinational companies can transfer renewable energy from advanced countries to deprived countries and conduct business more environmentally friendly. Abduli and Hamami (2017) studied the impact of strategic consumption, economic growth, FDI flows, trade openness on environmental degradation in 17 MENA countries. The study was gone through the static and dynamic panel data approach. They found that increase in economic growth in the inflow of FDI leads to the degradation of the environment in 17 MENA countries, i.e., emission of $\mathrm{CO} 2$ was increased due to industrialization through FDI inflow. Based on the findings, the study suggests 
improving the policy framework of the MENA countries to protect their environment and decrease

2 carbon emissions.

3 Rafindadi et al. (2018) This study uses Pooled Mean Group (PMG) Methodology to scrutinize the

4 impact of FDI inflows and energy consumption on pollution in the Gulf Cooperation Council. The

5 period of the study is 1990 to 2014. The findings show that FDI inflows have a negative environmental impact. In contrast, energy consumption has a positive stimulus, and that both factors are statistically significant in explaining the region's carbon emissions. More discretionary

8 income, local investment, and FDI all substantially impacted energy consumption in the Gulf

9 Cooperation Council. The study also showed how higher disposable income and FDI help the Gulf Cooperation Council enhance environmental quality. Domestic investment, on the other hand, reduces energy use. Furthermore, FDI harms the environment as a result of relative affluence. Our findings disproved the misconception that the GCC countries are pollution-free havens. Hussein and Ahmed (2019) premeditated the relationship between FDI and the economic growth of the Sultanate of Oman. This study applies the Multiple Regression model to find out the evidence regarding the impact of FDI on Oman's economic growth. The empirical result indicates that there is a positive relationship between FDI and the GDP of Oman. Result also explains that FDI is helping to find essential elements which are helpful to the domestic economy, i.e., skilled labor, entrepreneurship, technological know-how, and direct flow of foreign resources, including foreign exchange. Therefore, promoting these factors with the help of FDI will significantly impact existing domestic resources. The study findings suggested framing and applying better investment rules and regulations on FDI in Oman.

Li et al. (2020) investigate how environmental diplomacy affects a nation's greenhouse gases. We examine whether the signing of environmental treaties resulted in a reduction in $\mathrm{CO} 2$ emissions.

24 For almost 35 years, we use common correlated effects mean group models on panel data from 76 industrialized and developing nations. In the short term, environmental diplomacy appears to cut $\mathrm{CO} 2$ emissions for developing countries, according to our findings. However, the long-run projections of FMOLS show that rich and developing countries do not comply with treaty requirements as $\mathrm{CO} 2$ emissions rise as the number of treaties increases. Overall, our findings suggest that signing environmental treaties is more likely to constitute international diplomacy than climate change mitigation. We suggest that governments carry out their treaty obligations rather than indulging in periodic treaty signing rituals. 


\section{Methodology}

\subsection{Data and empirical model}

The study uses annual data of 40 years from 1980 to 2019 to draw inferences. The study variables are $\mathrm{CO}_{2}$ emissions as measured in metric tons per capita, Economic growth, Foreign Direct Investment, and Capital Investment as measured in billions of U.S. dollars. In addition, the data was collected from the Global Economic and World Development Indicator of the World Bank (2021) for empirical analysis.

The below equation depicts the functional relationship between $\mathrm{CO} 2$ emissions, economic growth, capital investment, and FDI, which are as follows:

$$
\ln C o_{2, t}=\beta_{0}+\beta_{1} \ln G D P_{t}+\beta_{2} \ln C I_{t}+\beta_{3} \ln F D I_{t}+\varepsilon_{t}
$$

$L n C o_{2, t}, \ln G D P_{t}, \operatorname{lnCI} I_{t}$ and $\ln F D I_{t}$ are the logarithmic forms of $\mathrm{CO}_{2}$ emission, capital investment, economic growth, and FDI.

\subsection{Unit root test}

In the series, the Zivot and Andrews (2002) unit route tests are applied under an endogenous structural division. This study applies three Zivot-Andrews unit root test specifications. Model Y denotes a break in the intercept only, model Q signifies a break in the trend, and model $\mathrm{W}$ represents a break in both the intercept and the trend. The following three models are as follows:

$$
\text { Model } Y: \Delta Y_{t}=\beta_{1}+\beta_{2} t+\delta Y_{t-1}+\theta P U_{t}+\sum_{i=1}^{r} \alpha i \Delta Y_{t-1}+\varepsilon_{t}
$$

$$
\text { Model } Q: \Delta Y_{t}=\beta_{1}+\beta_{2} t+\delta Y_{t-1}+\gamma P Q_{t}+\sum_{i=1}^{r} \alpha i \Delta Y_{t-1}+\varepsilon_{t}
$$

$$
\text { Model } W: \Delta Y_{t}=\beta_{1}+\beta_{2} t+\theta P U_{t}+\gamma P Q_{t}+\sum_{i=1}^{r} \alpha i \Delta Y_{t-1}+\varepsilon_{t}
$$

Where $P U_{t}=1$ and $P Q_{t}=t-T_{b}$ if $t>T_{b}$ and 0 otherwise. $T_{b}$ stances for a possible breakpoint.

\subsection{The bounds test for a level relationship.}

In the ARDL process, the bounds test is used to examine the long-term level relationship between

the given variables. The ARDL method was proposed by Pesaran et al. (2001), and can be used 
1 irrespective of the integration order of the regressors or whether (0) or I (1) are in independent

2 variables, or are in jointly cointegrated. The ARDL method propose the following error correction model (ECM);

$$
\begin{aligned}
& \Delta \ln C O_{2 t}=P_{O Y}+\sum_{i=0}^{s} q_{i Y} \Delta \ln C O_{2 t-i}+\sum_{i=0}^{s} r_{i Y} \Delta \ln C I_{t-i}+\sum_{i=0}^{s} s_{i Y} \Delta \ln G D P_{t-i} \\
& \quad+\sum_{i=0}^{s} t_{i Y} \Delta \ln F D I_{t-i}+\varphi_{1 Y} \ln C O_{2 t-1}+\varphi_{2 Y} \ln C I_{t-1}+\varphi_{3 Y} \ln G D P_{t-1} \\
& +\varphi_{4 Y} \operatorname{lnFDI}_{t-1}+\varepsilon_{t}
\end{aligned}
$$

Where $P_{O Y}$ and $\varepsilon_{t}$ are the intercepts and residual term. The dynamics of error correction and longrun relationship are shown in the first and second part of the equation, correspondingly. The bounds test in this study is based on two hypotheses. For example, the hypothesis of no cointegration between the variables in Eq (5) is $H_{o} \varphi_{I Y}=\varphi_{2 Y}=\varphi_{3 Y}=\varphi_{4 Y}=0$, which indicates the long-run relationship of the variables. The hypothesis of cointegration is $H_{1} \varphi_{I Y} \neq \varphi_{2 Y} \neq$ $\varphi_{3 Y} \neq \varphi_{4 Y} \neq 0$. The calculation of $\mathrm{F}$ statistics compares with the critical values of Shahbaz et al (2103). After finding the long-run association between variables, an error correction mechanism is applied to estimate the short-run coefficients and error correction terms. The ECM is interpreted in the following way:

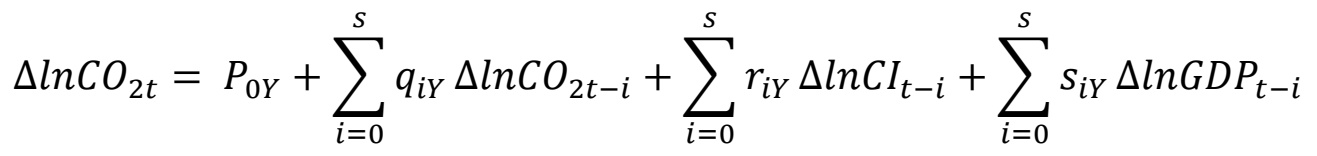

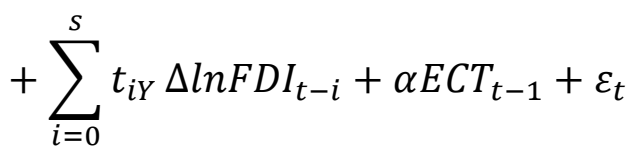

Where $E C T_{t-1}$ is an error correction term that signifies the speed of adjustment to the long-run equilibrium level? Diagnostic and stability tests determine the model's fit. In a model confirms a series of correlations, functional form, normality and heteroscedasticity are verified and using diagnostic tests. Pesaran and Pesaran (1997) suggest the cumulative sum (CUSUM) and cumulative sum of squares (CUSUMSQ) model stability measures proposed by Brown, Durbin, and Evans (1975).

\subsection{Causality test}


1 To assess the direction of causality between the variables, the Toda-Yamamoto (1995) causality

2 test is used. The most significant advantage of this test is that it can be used regardless of whether

3 the variables are integrated or the models have cointegration properties. The Modified Wald

4 statistic (MWALD) is recommended by Toda and Yamamoto (1995) for determining whether

5 variables have a causal relationship. In this technique, this form is used to measure VAR $(k+$

$6 d_{\max }$ ), where $k$ signifies the optimal order of the VAR model and $d_{\max }$ is the maximum

7 integration order. This study used the Hacker and Hatemi-J (2012) bootstrap test with endogenous

8 lag order and bootstrapped critical values are premeditated using 4000 simulations. The optimal

9 lag in the model is chosen using the information criteria of Hacker and Hatemi-J (2012).

10 The $\operatorname{VAR}\left(k+d_{\text {max }}\right)$ model can be calculated using the following formula:

$\ln \mathrm{CO}_{2}=\alpha_{0}+\sum_{i=1}^{k} \alpha_{1 i} \operatorname{lnCO_{2,t-i}}+\sum_{j=k+1}^{d_{\max }} \alpha_{2 j} \ln C \mathrm{O}_{2, t-j}+\sum_{i=1}^{k} \beta_{1 i} \ln C I_{t-i}+\sum_{j=k+1}^{d_{\max }} \beta_{2 j} \ln C I_{t-j}$

$$
+\sum_{i=1}^{k} \delta_{1 i} \ln G D P_{t-i}+\sum_{j=k+1}^{d_{\max }} \delta_{2 j} \ln G D P_{t-j}+\sum_{i=1}^{k} \gamma_{1 i} \ln F D I_{t-i}+\sum_{j=k+1}^{d_{\max }} \gamma_{2 j} \ln F D I_{t-j}
$$

$$
+\varepsilon_{1 t}
$$

14

$\ln C I=\beta_{0}+\sum_{i=1}^{k} \beta_{1 i} \ln C I_{t-i}+\sum_{j=k+1}^{d_{\max }} \beta_{2 j} \ln C I_{t-j}+\sum_{i=1}^{k} \varphi_{1 i} \ln C O_{2, t-i}+\sum_{j=k+1}^{d_{\max }} \varphi_{2 j} \ln C O_{2, t-j}$

$$
+\sum_{i=1}^{k} \delta_{1 i} \ln G D P_{t-i}+\sum_{j=k+1}^{d_{\max }} \delta_{2 j} \ln G D P_{t-j}+\sum_{i=1}^{k} \gamma_{1 i} \ln F D I_{t-i}+\sum_{j=k+1}^{d_{\max }} \gamma_{2 j} \ln F D I_{t-j}
$$

$$
+\varepsilon_{2 t}
$$

18

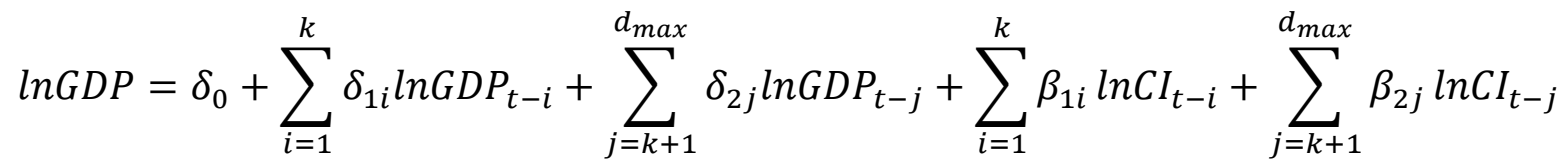

$$
+\sum_{i=1}^{k} \varphi_{1 i} \ln C O_{2, t-i} \sum_{j=k+1}^{d_{\max }} \varphi_{2 j} \ln C O_{2, t-j}+\sum_{i=1}^{k} \gamma_{1 i} \ln F D I_{t-i}+\sum_{j=k+1}^{d_{\max }} \gamma_{2 j} \ln F D I_{t-j}
$$

$$
+\varepsilon_{3 t}
$$




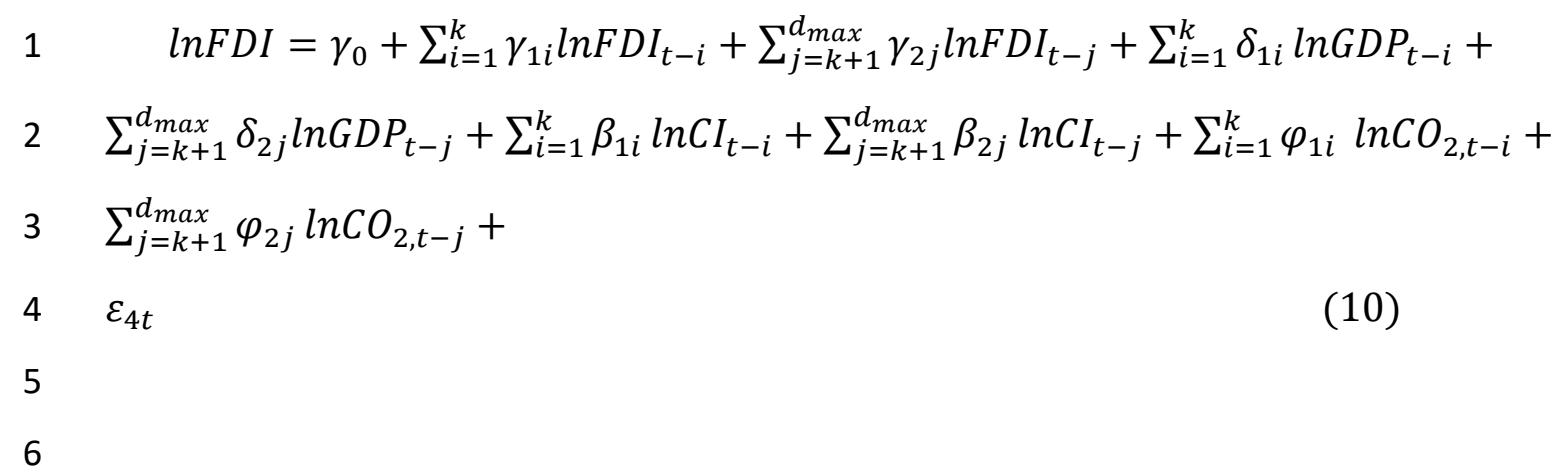

\section{$7 \quad 3.5$ The asymmetric analysis}

8 To find out the asymmetric relation between $\mathrm{CO}_{2}$ and other explanatory variables, we used the 9 NARDL methodology of Shin et al. (2014) to capture a non-linear relationship. However, the linear ARDL model ignores the possible asymmetric link. Thus, according to Shin et al. (2014),

11 equation five can be rewritten as follows:

$$
\Delta \operatorname{lnCO} O_{2 t}=\delta_{0}+\delta_{1} \operatorname{lnCO} 2 t-1+\delta_{2} \operatorname{lnCI_{t-1}^{+}}+\delta_{3} \ln C I_{t-1}^{-}+\delta_{3} \ln G D P_{t-1}^{+}+\delta_{4} \ln G D P_{t-1}^{-}
$$

$$
+\delta_{5} \ln F D I_{t-1}^{+}+\delta_{6} \ln F D I_{t-1}^{-}+\sum_{i=1}^{p} \tau_{i} \Delta \ln C O_{2, t-i}+\sum_{i=0}^{q}\left(\tau_{i}^{+} \Delta \ln C I_{t-i}^{+}\right.
$$

4

From Equation 11, $\delta_{i}^{+}\left(\sum_{i=1}^{q} \tau_{i}^{+}\right)$and $\delta_{i}^{-}\left(\sum_{i=1}^{q} \tau_{i}^{-}\right)$signifies the long (short)-run positive and negative effects of GDP, $\mathrm{CI}$, and FDI on $\mathrm{CO}_{2}$. In the ARDL model, the bound test is performed to see if the variables are co-integrated asymmetrically or not. However, the wald test is also used to determine whether GDP, CI, and FDI have a long (short)-run symmetric relationship $\delta=\delta^{+}=$ $\delta^{-}\left(\tau=\tau^{+}=\tau^{-}\right)$. The short-term asymmetric association can be established utilizing the dynamic multiplier effect after the nonlinear relationship has been validated. The dynamic multiplier effect can be applied in this study by using the following formula:

$W_{q}^{+}=\sum_{j-0}^{r} \frac{\vartheta \ln C O_{2, t-j}}{\vartheta \ln C I_{t-i}^{+}}, W_{q}^{-}=\sum_{j-0}^{r} \frac{\vartheta \ln C O_{2, t-j}}{\vartheta \ln C I_{t-i}^{-}}$

$25 \quad W_{q}^{+}=\sum_{j-0}^{r} \frac{\vartheta \ln C O_{2, t-j}}{\vartheta \ln G D P_{t-i}^{+}}, W_{q}^{-}=\sum_{j-0}^{r} \frac{\vartheta \ln C O_{2, t-j}}{\vartheta \ln G D P_{t-i}^{-}}$ 
$2 \quad W_{q}^{+}=\sum_{j-0}^{r} \frac{\vartheta \ln C O_{2, t-j}}{\vartheta \ln F D I_{t-i}^{+}}, W_{q}^{-}=\sum_{j-0}^{r} \frac{\vartheta \ln C O_{2, t-j}}{\vartheta \ln F D I_{t-i}^{-}}$

$3 \mathrm{q}=0,1,2,3 \ldots$

4

$5 \quad$ Where $\mathrm{q} \rightarrow \infty$, then $W_{q}^{+} \rightarrow \delta^{+}$and $W_{q}^{-} \rightarrow \delta^{-}$.

6 4. Results and their discussions

7 The Zivot and Andrews' (2002) unit root test for one structural break in the series is shown in

8 Table 1. The empirical results of unit route test indicate that the unit roots of the level of $\operatorname{lnCO} 2$

9 and $\operatorname{lnCI}$ are under a structural break, it shows that they are not stationary at their levels. Once the

10 first difference is taken, they become stationary. On the contrary, we can reject the null hypothesis

11 of a unit root under one structural break of $\operatorname{lnFDI}$ and $\operatorname{lnGDP}$, implying that $\operatorname{lnCO} 2$ and $\operatorname{lnCI}$ are

12 stationary at their level forms. Our empirical evidence of Zivot and Andrews (2002) discloses that

13 the independent variables $\operatorname{lnCO}_{2}$ and $\operatorname{lnCI}$ are integrated of order one, or I (1). In contrast, lnFDI 14 and $\operatorname{lnGDP}$ are integrated of order zero, or I (0).

Table 1. Zivot Andrews Unit Root test

\begin{tabular}{|c|c|c|c|c|c|c|c|}
\hline \multicolumn{4}{|c|}{ Statistics (Level) } & \multicolumn{4}{|c|}{ Statistics (First Difference) } \\
\hline & $Z A_{B}$ & $Z A_{T}$ & $Z A_{I}$ & $Z A_{B}$ & $Z A_{T}$ & $Z A_{I}$ & Conclusion \\
\hline $\mathrm{LnCo}_{2}$ & -4.176 & -2.812 & -3.610 & $-3.656^{*}$ & -3.645 & $-3.069 *$ & \multirow{3}{*}{$1(1)$} \\
\hline Break Year & 2005 & 2012 & 2001 & 2005 & 2012 & 2013 & \\
\hline Lag-length & 0 & 0 & 0 & 0 & 1 & 0 & \\
\hline & & & & & & & \\
\hline LnFDI & $-4.284 * * *$ & $-4.021 * *$ & -3.918 & $-4.808 * *$ & $-5.604 * *$ & $-5.110 * *$ & \multirow{3}{*}{$1(0)$} \\
\hline Break Year & 2004 & 2000 & 2004 & 2007 & 2012 & 2007 & \\
\hline Lag-length & 0 & 0 & 0 & 1 & 1 & 1 & \\
\hline & & & & & & & \multirow{4}{*}{$1(0)$} \\
\hline LnGDP & -3.071 & -2.833 & -3.609 & $-3.434 * *$ & $-3.366^{* *}$ & -2.129 & \\
\hline Break Year & 2005 & 1998 & 2006 & 2013 & 2014 & 2013 & \\
\hline Lag length & 0 & 0 & 0 & 4 & 4 & 0 & \\
\hline & & & & & & & \multirow{4}{*}{$1(1)$} \\
\hline LnCI & $-4.422 *$ & -3.200 & -5.136 & $-5.370 *$ & $-5.240 *$ & $-4.261 * *$ & \\
\hline Break Year & 2005 & 1995 & 2005 & 2011 & 2013 & 2013 & \\
\hline Lag length & 0 & 0 & 0 & 0 & 4 & 0 & \\
\hline
\end{tabular}

Source: Authors own calculation using Eviews 12.

The model with a break in both the trend and the intercept is designated by $Z A_{B}$; the model with a break in the trend is designated by $Z A_{T}$; and the model with a break in the intercept is designated by $Z A_{I} *^{*},{ }^{* *}$, and ${ }^{* * *}$ represent the null hypothesis rejection at the $1 \%, 5 \%$, and $10 \%$ levels, correspondingly. 
2 The unit root test revealed that the variables have a mixed order of integration. The next step is to apply the ARDL bounds test to determine the long-run association between $\mathrm{CO}_{2}$ emissions, capital investment, GDP, and foreign direct investment (Pesaran, Shin, and Smith 2001). The outcome of the bound test is shown in Table 2, which demonstrates that the valve of F-statistics is more than the upper critical bound at the 5\% and $1 \%$ levels; as a result, the null hypothesis of no cointegration is rejected. This stipulates that the variables are cointegrated for a long-run relationship between capital investment, foreign direct investment, gross domestic product, and $\mathrm{CO}_{2}$ emission in Oman.

Table 2. Bound Test for Level relationship

\begin{tabular}{|l|l|l|l|l|}
\hline \multicolumn{2}{|l|}{ F-Bounds Test } & \multicolumn{2}{l|}{} \\
\hline Test Statistic & Value & Sign in. & $1(0)$ & $1(1)$ \\
& & & & \\
\hline & & $10 \%$ & Asymptotic: $\mathrm{n}=1000$ & \\
\hline F-statistic & 11.78917 & $5 \%$ & 2.97 & 3.74 \\
\hline $\mathrm{k}$ & 3 & $2.5 \%$ & 3.38 & 4.23 \\
\hline & & $1 \%$ & 3.8 & 4.68 \\
\hline
\end{tabular}

Source: Author's calculation using Eviews 12.

12 The bound test reveals that the variables have a long-term equilibrium relationship. To estimate long-run and short-run coefficients, the ARDL model should be applied. The diagnostic test results for the ARDL model are reported in Table 3. The findings support the cogency of the ARDL model. Because our model is reliable and free from any econometric problem, the ARDL model's stability should be assessed through CUSUM and CUSUMSQ, shown in Figures 1, respectively. The graph plot of both stability tests indicates that the ARDL model is stable and consistent in the 18 short and long run.

Table 3. Diagnostic Test Results

\begin{tabular}{|l|l|l|}
\hline Diagnostic Test & Test statistics & P-valve \\
\hline Serial Correlation & 0.9923 & 0.3924 \\
\hline Functional Form & 0.1611 & 0.2641 \\
\hline Normality & 1.7973 & 0.4071 \\
\hline Heteroscedasticity & 0.4482 & 0.9492 \\
\hline
\end{tabular}



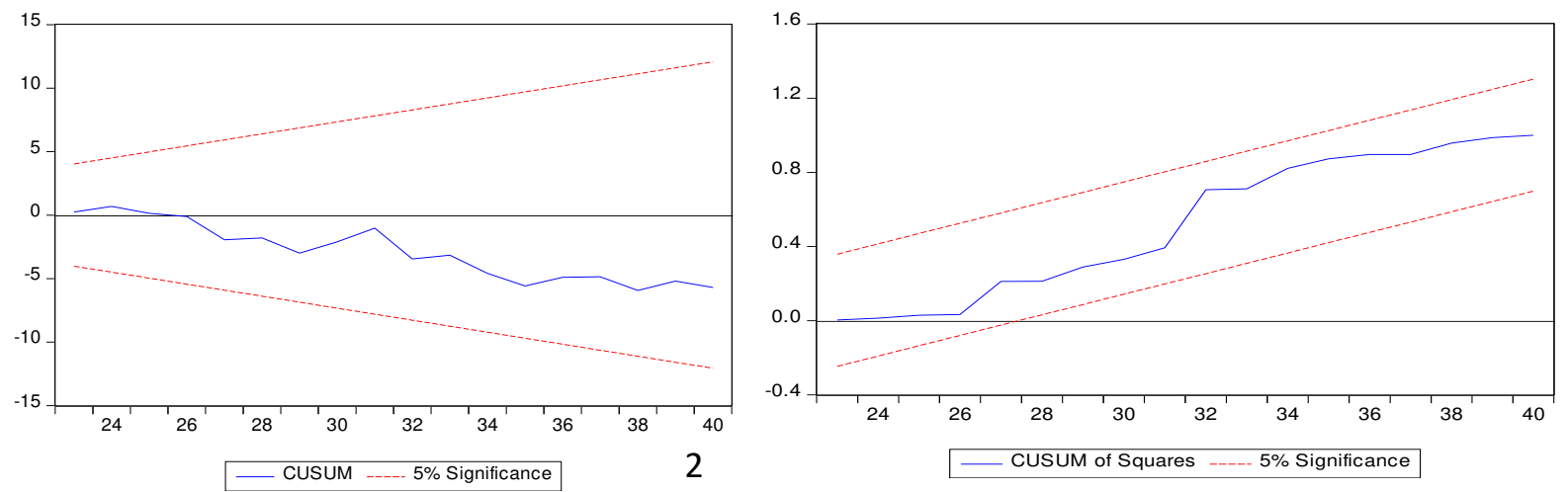

Note: At the 5\% significance level, the straight lines signify critical bounds.

4 The empirical evidence of long-term coefficients of the ARDL model is shown in Table 4. The findings reveal that $\operatorname{lnFDI}$ and $\operatorname{lnGDP}$ have a positive, inelastic, and statistically significant impact on $\mathrm{CO}_{2}$ emission in the long run. Whereas $\operatorname{lnCI}$ has a statistically significant, elastic, and adverse effect on $\mathrm{CO}_{2}$ emissions. However, increased economic growth and foreign direct investment raise pollution levels in Oman, whereas capital investment reduces $\mathrm{CO}_{2}$ emissions in the long -run.

Table 4. Level coefficients in the long-term model through the ARDL approach

\begin{tabular}{|l|l|l|l|l|}
\hline & \multicolumn{4}{|c|}{ Regressors } \\
\hline $\begin{array}{l}\text { Dependent variable } \ln \\
\mathrm{Co}_{2}\end{array}$ & LnFDI & LNGDP & LNCI & Intercept \\
\hline $\ln \mathrm{Co}_{2}$ & $0.134^{*}$ & $0.297^{*}$ & $-0.684^{* *}$ & $1.984^{*}$ \\
\hline Coefficient & $(0.000)$ & $(0.000)$ & $(0.000)$ & $(0.000)$ \\
\hline
\end{tabular}

Source: Author's calculation using Eviews 12.

Note: In each model, the numbers in parentheses are the prob. values of the t-statistics. *, **, and *** indicate statistical significance at the $1 \%, 5 \%$, and $10 \%$ levels, respectively.

13 The findings of the conditional ECM using the ARDL technique are shown in Table 5. The coefficient of the ECM model is (-0.501), which signifies that $\mathrm{CO}_{2}$ emissions in Oman converged to their long-run equilibrium level by a $50.1 \%$ speed of adjustment every year due to the involvement of FDI, economic growth, and capital investment. At varied lag lengths, all independent variables have a statistically significant short-term impact on $\mathrm{CO}_{2}$ emissions. Furthermore, when GDP rises by $1 \%, \mathrm{CO}_{2}$ emissions in the country rise by 0.308 percent at the second lag. At different lag levels, the short-term coefficients of capital investment and FDI positively associate with air pollution.

Table 5. Conditional error correction model through the ARDL approach

\begin{tabular}{|l|l|l|l|}
\hline \multicolumn{5}{|c|}{ Dependent variable: $\operatorname{lnCO}_{2}(3,3,4,4) *$} \\
\hline Regressor & Coefficient & Standard Error & p-valve \\
\hline Ect (-1) & -0.501 & 0.059 & 0.000 \\
\hline
\end{tabular}




\begin{tabular}{|l|l|l|l|}
\hline$\Delta \ln \mathrm{Co}_{2} t_{-1}$ & -0.531 & 0.208 & 0.027 \\
\hline$\Delta \ln \mathrm{Co}_{2} t_{-2}$ & -0.286 & 0.194 & 0.158 \\
\hline$\Delta \ln \mathrm{Co}_{2} t_{-3}$ & -0.493 & 0.149 & 0.004 \\
\hline$\Delta \operatorname{lnFDI}$ & -1.566 & 0.552 & 0.110 \\
\hline$\Delta \operatorname{lnFDI} t_{-1}$ & 0.256 & 0.305 & 0.000 \\
\hline$\Delta \operatorname{lnFDI} t_{-2}$ & 0.134 & 0.584 & 0.001 \\
\hline$\Delta \operatorname{lnGDP}$ & -0.112 & 0.038 & 0.008 \\
\hline$\Delta \operatorname{lnGDP} t_{-1}$ & 0.360 & 0.069 & 0.000 \\
\hline$\Delta \operatorname{lnGDP} t_{-2}$ & 0.308 & 0.063 & 0.000 \\
\hline$\Delta \operatorname{lnGDP} t_{-3}$ & 0.297 & 0.056 & 0.000 \\
\hline$\Delta \operatorname{lnCI}$ & 0.070 & 0.081 & 0.397 \\
\hline$\Delta \operatorname{lnCI} t_{-1}$ & 0.104 & 0.246 & 0.003 \\
\hline$\Delta \operatorname{lnCI} t_{-2}$ & -0.559 & 0.136 & 0.007 \\
\hline$\Delta \operatorname{lnCI} t_{-3}$ & -0.684 & 0.125 & 0.000 \\
\hline Intercept & 1.984 & 0.236 & 1.000 \\
\hline Adj. $R 2$ & 0.862 & S.E. of Regression & 0.519 \\
\hline AIC & 1.109 & SBC & 2.428 \\
\hline F. Stat & 10.587 & F. prob & 0.000 \\
\hline D.W. stat & 2.543 & & \\
\hline S. & A & & \\
\hline
\end{tabular}

1 Source: Author's calculation using Eviews 12.

2 Note: * "p-lag structure in the model."

4 To evaluate the existence and direction of relationships between variables, the Toda-Yamamoto 5 (1995) causality test is used. Table 6 shows a bidirectional relationship between carbon emissions and FDI in Oman, implying that FDI causes $\mathrm{CO}_{2}$ emission and $\mathrm{CO}_{2}$ emission causes FDI. Furthermore, there is a bidirectional relationship between economic growth and $\mathrm{CO}_{2}$ emission, meaning that changes in economic growth lead to changes in $\mathrm{CO}_{2}$ emission and vice versa. Capital investment and $\mathrm{CO}_{2}$ emission, on the other hand, have a one-way causal relationship. Hence the capital investment growth hypothesis is irrelevant in Oman. Mutafoglu (2012) similarly confirms

11 the unidirectional causality of capital investment to GDP, concluding that there is no evidence of 12 the capital investment-led growth hypothesis in the Oman economy.

13 Furthermore, there are bidirectional causal links between FDI to GDP and capital investment to 14 FDI. There was no evidence of a causal relationship between $\mathrm{CO}_{2}$ and capital investment in Oman or GDP to capital investment. These results are relevant to the studies of (Chandran and Tang, 162013 and Shahbaz, 2013).

Table 6. Toda Yamamato Causality Test

\begin{tabular}{|l|l|l|l|}
\hline Hypothesis & Chi-square & P-valve & Decision \\
\hline $\operatorname{lnFDI}$ does not cause $\operatorname{lnCO}_{2}$ & 16.99762 & 0.0043 & Reject \\
\hline $\operatorname{lnCI}$ does not cause $\operatorname{lnCO} 2$ & 12.93827 & 0.0440 & Reject \\
\hline $\ln \mathrm{CDP}$ does not cause $\operatorname{lnCO} 2$ & 23.88876 & 0.0005 & Reject \\
\hline $\ln \mathrm{CO}_{2}$ does not cause $\operatorname{lnFDI}$ & 24.03150 & 0.0005 & Reject \\
\hline $\operatorname{lnCI}$ does not cause $\operatorname{lnFDI}$ & 17.29254 & 0.0033 & Reject \\
\hline
\end{tabular}




\begin{tabular}{|l|l|l|l|}
\hline $\operatorname{lnGDP}$ does not cause $\operatorname{lnFDI}$ & 25.37930 & 0.0003 & Reject \\
\hline $\operatorname{lnCO} 2$ does not cause $\operatorname{lnCI}$ & 8.841954 & 0.1827 & Fail to Reject \\
\hline $\ln \mathrm{FDI}$ does not cause $\operatorname{lnCI}$ & 16.24845 & 0.0125 & Reject \\
\hline $\ln \mathrm{GDP}$ does not cause $\operatorname{lnCI}$ & 1.958783 & 0.9235 & Fail to Reject \\
\hline $\ln \mathrm{CO}_{2}$ does not cause $\ln \mathrm{GDP}$ & 65.00015 & 0.0000 & Reject \\
\hline $\ln \mathrm{FDI}$ does not cause $\operatorname{lnGDP}$ & 38.64454 & 0.0000 & Reject \\
\hline $\ln \mathrm{CI}$ does not cause $\operatorname{lnGDP}$ & 14.85320 & 0.0214 & Reject \\
\hline
\end{tabular}

1

2 3

4

Source: Author's calculation using Eviews 12.

Note: 4000 simulations are run to establish the bootstrapped critical valve criterion for the optimal lag length selection.

The outcome of the nonlinear bound test is shown in Table 7, which demonstrates that the valve of F-statistics is 11.785, which is more than the upper critical bound at the 5\% and 1\% levels; as a result, the null hypothesis of no cointegration is rejected. This stipulates that the variables are cointegrated for a long-run relationship among the $\mathrm{CO}_{2}, \ln F D I_{- \text {pos, }} \ln F D I_{-n e g}$, $\ln G D P_{-p o s,} \ln G D P_{-p o s,} \ln C I_{-p o s,}$ and $\ln C I_{-p o s \text {, }}$

\section{Table 7. Bound Test for nonlinear cointegration}

\begin{tabular}{|l|c|r|r|r|}
\hline F-Bounds Test & \multicolumn{3}{|r|}{ Null Hypothesis: No levels relationship } \\
\hline Test Statistic & Value & Sign in. & I (0) & I (1) \\
\hline & & & $\begin{array}{c}\text { Asymptotic: } \\
\text { n=1000 }\end{array}$ & 3.25 \\
\hline F-statistic & 11.78519 & $10 \%$ & 2.33 & 3.62 \\
\hline $\mathrm{k}$ & 6 & $5 \%$ & 2.63 & 3.94 \\
\hline & & $2.5 \%$ & 2.9 & 4.39 \\
\hline
\end{tabular}

Source: Author's calculation using Eviews 12.

The empirical findings for the diagnostic tests are shown in Table 8. We used the Jarque-Bera test to determine data normality, where the Chi-square test critical value is greater than 5\%, demonstrating statistical insignificance and failure to reject the null hypothesis of the normal distribution, showing that the data is normally distributed. In heteroscedasticity, we used the Breusch-Pagan (B.P.) test in conjunction with the ARCH test. We discovered that the resulting probability value of the Chi-square test was statistically insignificant, indicating that the null hypothesis of homoscedasticity was not rejected. In addition, we checked the stability of the model incorporating the cumulative sum of recursive residuals (CUSUM) and cumulative sum of recursive residual square (CUSUMSQ). The graph plots for CUSUM and CUSUMSQ are shown in Figure 2, demonstrating that all models are dynamically stable.

Table 8. Diagnostic test for NARDL

\begin{tabular}{|l|l|l|}
\hline Test & F-statistics & P-valve \\
\hline Normality & 0.865 & 0.648 \\
\hline Serial Correlation & 0.324 & 0.726 \\
\hline ARCH & 0.082 & 0.775 \\
\hline
\end{tabular}




\begin{tabular}{|l|l|l|}
\hline Heteroscedasticity & 0.853 & 0.617 \\
\cline { 1 - 2 } CUSTOM & \multicolumn{1}{|c|}{ Stable } \\
\cline { 1 - 1 } CUSUM-SQ & Stable & \\
\cline { 1 - 2 }
\end{tabular}

Source: Author's calculation using Eviews 12.

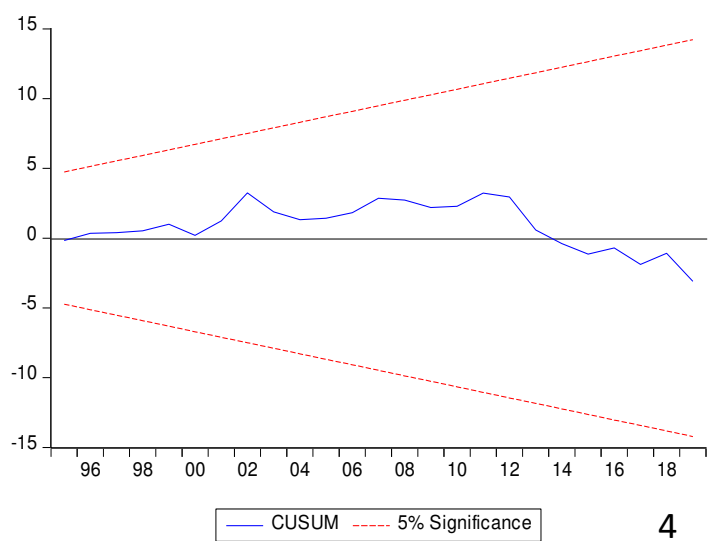

\section{Figure 2. Plots of CUSUM and CUSUMSQ for Model Stability}

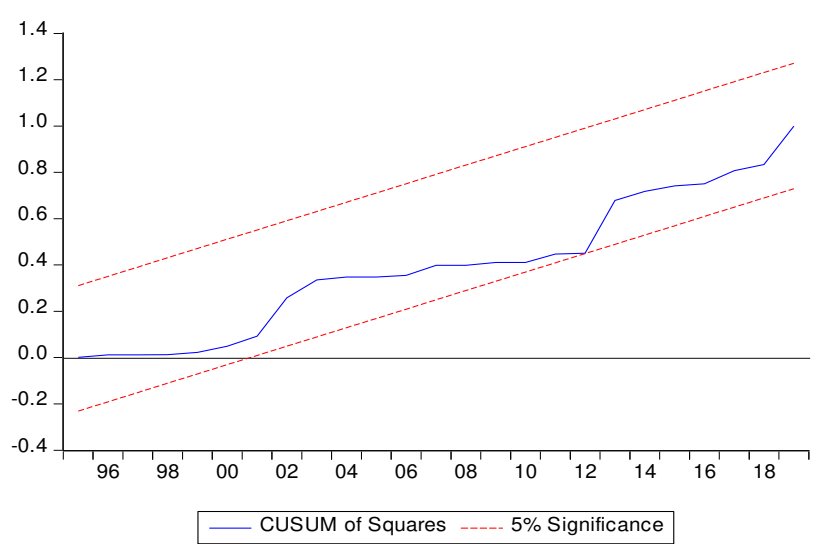

Note: The straight lines signify critical bounds at the 5\% significance level.

We used the Wald test for both long-run $\left(W_{L R}\right)$ and short-run $\left(W_{S R}\right)$ symmetries to ensure that an asymmetric model was adequate. The results in the lower part of Table 9 for the long-run time horizon show that the null hypothesis of long-run symmetry between the positive and negative components of each of the analyzed variables is rejected. More explicitly, the Wald test for the long run shows that all the three explanatory variables are significant, which means an asymmetry. Before looking at the magnitude of these long-run asymmetric repercussions, we first look at the short-run dynamics. In the short term, the Wald statistic is used to compare the null hypothesis of symmetry against the alternative of asymmetry: $\delta_{i}^{+}\left(\sum_{i=1}^{q} \tau_{i}^{+}\right)$and $\delta_{i}^{-}\left(\sum_{i=1}^{q} \tau_{i}^{-}\right)$respectively. The results show that the null hypothesis of a weak form of symmetric adjustment $\left(W_{S R}\right)$ is rejected for all included variables. More specifically, the Wald test for FDI components is 43.196 (pvalue $=0.000$ ), whereas the Wald test for GDP components is 8.827 (p-value $=0.006$ ), and the Wald test for CI components is 11.053 (pvalve $=0.002$ ).

The findings of the NARDL model for long-run and short-run estimations are reported in Table 9. The long-run results report that FDI is significant for both positive $\left(L_{F D I}^{+}\right)$and negative $\left(L_{F D I}^{-}\right)$ shocks. It suggests that FDI will bring positive effects on the $\mathrm{CO}_{2}$ emission of Oman in the long run. The estimated results for long-run coefficients of $\left(L_{F D I}^{+}\right)$and $\left(L_{F D I}^{-}\right)$are found 1.52 and 0.73 , respectively, revealing a $1 \%$ rise in FDI rises $1.52 \%$ of $\mathrm{CO}_{2}$ emission in Oman. Similarly, a $1 \%$ 
fall in FDI will reduce $\mathrm{CO}_{2}$ by $0.73 \%$. This demonstrates that Oman's foreign direct investment is

$2 \mathrm{CO}_{2}$ efficient.

3 Meanwhile, improving living standards needs a higher quality of life and rigorous environmental

4 rules, and FDI brings more advanced technology that minimizes the country's pollution level.

5 These outcomes are reliable with Shahbaz et al. (2017). Regarding GDP, GDP results are

6 significant for both positive $\left(L_{G D P}^{+}\right)$and negative $\left(L_{G D P}^{-}\right)$shocks. The estimated long-run

7 coefficients of $\left(L_{G D P}^{+}\right)$and $\left(L_{G D P}^{-}\right)$are reported as 0.02 and 0.10 , respectively. Hence, we conclude

8 that a $1 \%$ rise in GDP leads to $\mathrm{CO}_{2}$ emission by $0.02 \%$.

9 Similarly, the negative shock of GDP is also significant with a positive sign. As a result, our

10 findings show that negative changes have a more significant impact. GDP and $\mathrm{CO}_{2}$ emissions have

11 a positive connotation, suggesting that as GDP rises, production upsurges, increased production

12 escalations the demand of labor and per capita income in the country, so does the usage of $\mathrm{CO}_{2}$

13 emission increases. Consequently, GDP is a source to increase $\mathrm{CO}_{2}$ emissions in Oman. These

14 results are consistent with Aqeel et al. (2001) and Shahbaz et al. (2017). In the long run, positive shocks to capital investment have a significant impact on $\mathrm{CO}_{2}$ emission. It is in line with recent studies like Luqman et al. (2019) for Pakistan and Ghazouani (2021) for Tunisia, where they have

17 found a positive effect of capital formation on $\mathrm{CO}_{2}$ emission. On the other hand, a negative shock to capital investment is insignificant and has a negative impact on $\mathrm{CO}_{2}$ emission (a coefficient of $0.39)$.

20 In the short run, the decomposed factors with positive and negative shocks have similar effects as they do in the long run. On the other hand, the degrees of elasticity differ slightly, but the relations are nearly identical. The ECM reflects the change in disequilibrium inaccuracy over time in the short term. The estimated methodology maps the progressive adjustment towards the new equilibrium after the shocks from the initial equilibrium. The error correction term (ECT) is negative and statistically significant at a level of $1 \%$. According to ECT, roughly $53 \%$ of the path to long-run equilibrium is completed a year following an economic shock. The adjusted R-square of the model is 0.93 , indicating that independent factors account for 93.60 percent of the dependent variable. The adjusted R-Square confirms the model's specification. The Durbin-Watson test suggests no autocorrelation problem in the series, with a value of 2.05. The D.W. test has a decision criterion of 1.5 to 2.5 . The series does not have an autocorrelation if the value is between these boundaries. 
Table 9. NARDL estimation of long-run and short-run

\begin{tabular}{|c|c|c|c|}
\hline \multicolumn{4}{|c|}{$\begin{array}{l}\text { Dependent variable: } \ln \mathrm{CO}_{2} \\
\text { Long run estimation }\end{array}$} \\
\hline Variable & Coefficient & t-Statistic & Prob. \\
\hline lnFDI_POS & 1.528 & 4.574 & $0.0002 * *$ \\
\hline lnFDI_NEG & -0.732 & -4.182 & $0.0004 * *$ \\
\hline lnGDP_POS & 0.021 & 1.345 & $0.0114 * *$ \\
\hline lnGDP_NEG & 0.102 & 8.171 & $0.0401 * *$ \\
\hline lnCI_POS & 0.328 & 5.072 & $0.0001 *$ \\
\hline lnCI_NEG & 0.039 & 1.253 & 0.2238 \\
\hline Constant & -0.029 & -2.636 & $0.0208 * *$ \\
\hline \multicolumn{4}{|l|}{ Short run estimation } \\
\hline Variable & Coefficient & t-Statistic & Prob. \\
\hline$\Delta \operatorname{lnFDI} \_P O S$ & 0.067 & 1.278 & $0.0105 * *$ \\
\hline$\Delta \operatorname{lnFDI}$ _NEG & -0.140 & -4.519 & $0.0002 * *$ \\
\hline$\Delta \operatorname{lnGDP} \_P O S$ & 4.886 & 7.994 & $0.0000^{*}$ \\
\hline$\Delta \operatorname{lnGDP} \_N E G$ & 2.341 & 4.548 & $0.0232 * *$ \\
\hline$\Delta \operatorname{lnCI} \overline{P O S}$ & 1.050 & 5.137 & $0.0000^{*}$ \\
\hline$\Delta \operatorname{lnCI}=$ NEG & 0.124 & 1.231 & 0.2318 \\
\hline Count Eq & -0.104 & -7.772 & $0.0000^{*}$ \\
\hline R-squared & 0.962705 & Mean dep var & -0.149459 \\
\hline Adjusted R-squared & 0.936066 & S.D. dep var & 2.609201 \\
\hline S.E. of regression & 0.659742 & AIC & 2.304532 \\
\hline Sum squared resid & 9.140437 & $\mathrm{SC}$ & 3.001145 \\
\hline Log-likelihood & -26.63385 & $\mathrm{HC}$ & 2.550121 \\
\hline F-statistic & 36.13864 & DW & 2.055801 \\
\hline Prob(F-statistic) & 0.000000 & & \\
\hline \multicolumn{4}{|l|}{ Wald test results } \\
\hline & F-stat & Prob & \\
\hline$F D I_{W L R}$ & 11.152 & $0.002 * *$ & \\
\hline$F_{E W E R}$ & 43.196 & $0.000 *$ & \\
\hline$G D P_{W L R}$ & 0.498 & $0.027 * *$ & \\
\hline$G D P_{W S R}$ & 8.827 & $0.006^{* * * *}$ & \\
\hline$C I_{W L R}$ & 14.770 & $0.000 *$ & \\
\hline VIEW & 11.053 & $0.002 * *$ & \\
\hline
\end{tabular}

2 Note: *,** and *** represents significance level at $1 \%, 5 \%$ and $10 \% . W_{L R}$ and $W_{S R}$ signify the Wald test for the

3 null of long-run and short-run asymmetries for the given variables.

4 The asymmetric cumulative dynamic multiplier for capital investment, economic growth, and

5 foreign direct investment are depicted in Figure 3. The positive and negative unitary shocks in

6 every explanatory variable follow the adjustment pattern of capital investment, economic growth,

7 and foreign direct investment to the new state of balance. The dynamic multipliers reflect this. As

8 indicated in Table 9, the best-fit NARDL model estimates this dynamic multiplier. The modulated

9 pattern of the dependent variable $\left(\mathrm{CO}_{2}\right)$ to positive and negative shocks of the independent

10 variables (capital investment, economic growth, and foreign direct investment) is captured by the

11 solid black line (positive) and the dotted black line (negative) with breaks. The red dotted line 
1 shows the asymmetry, which indicates the change in dynamic multipliers linked to each 2 explanatory variable's shocks, i.e. $\left(w_{q}^{+}-w_{q}^{-}\right)$. This curve is displayed in its entirety, with the 3 bottom and top bands at a 95 percent confidence interval to provide a statistically meaningful 4 estimate of asymmetry at any q-defined horizon. If the zero lines are found in the middle of the 5 two bands, then the explanatory variable in consideration has insignificant asymmetric effects (see 6 Fig. 4).

7 8

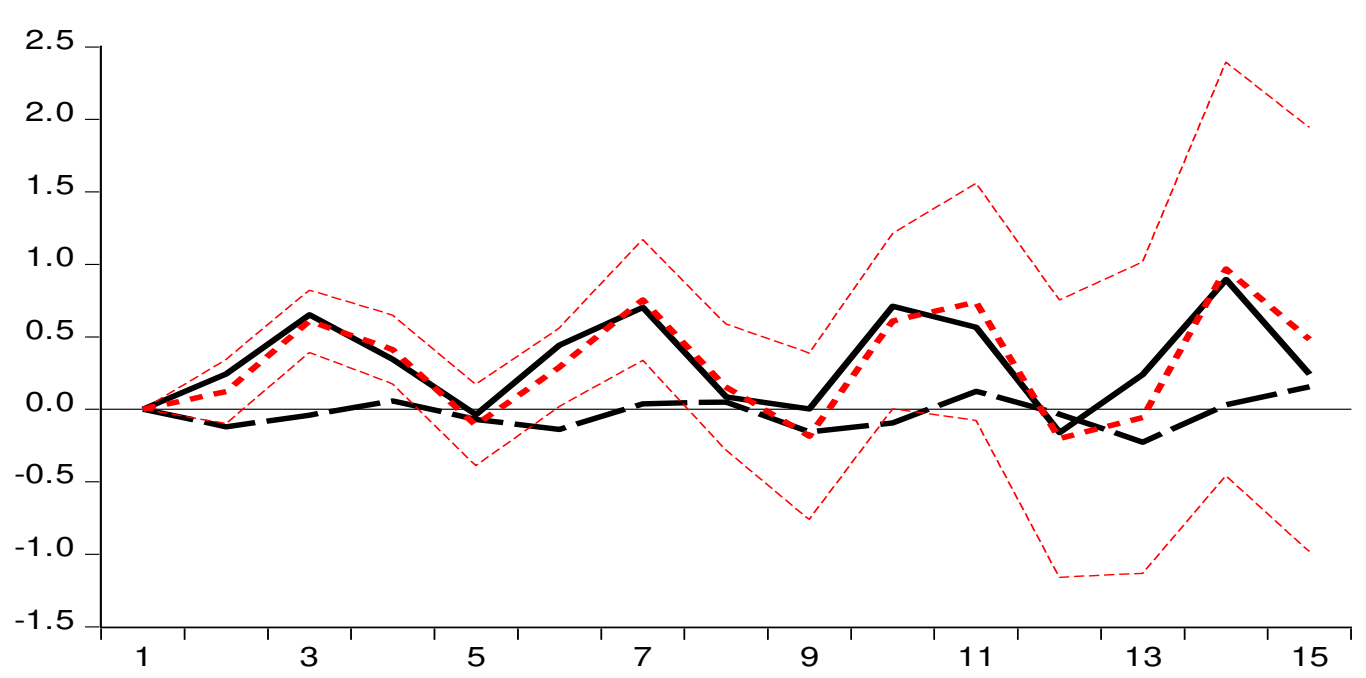

\section{Multiplier for $\mathrm{Cl}(+)$ \\ - Multiplier for $\mathrm{Cl}(-)$ \\ --- Asymmetry Plot (with C.I.)}

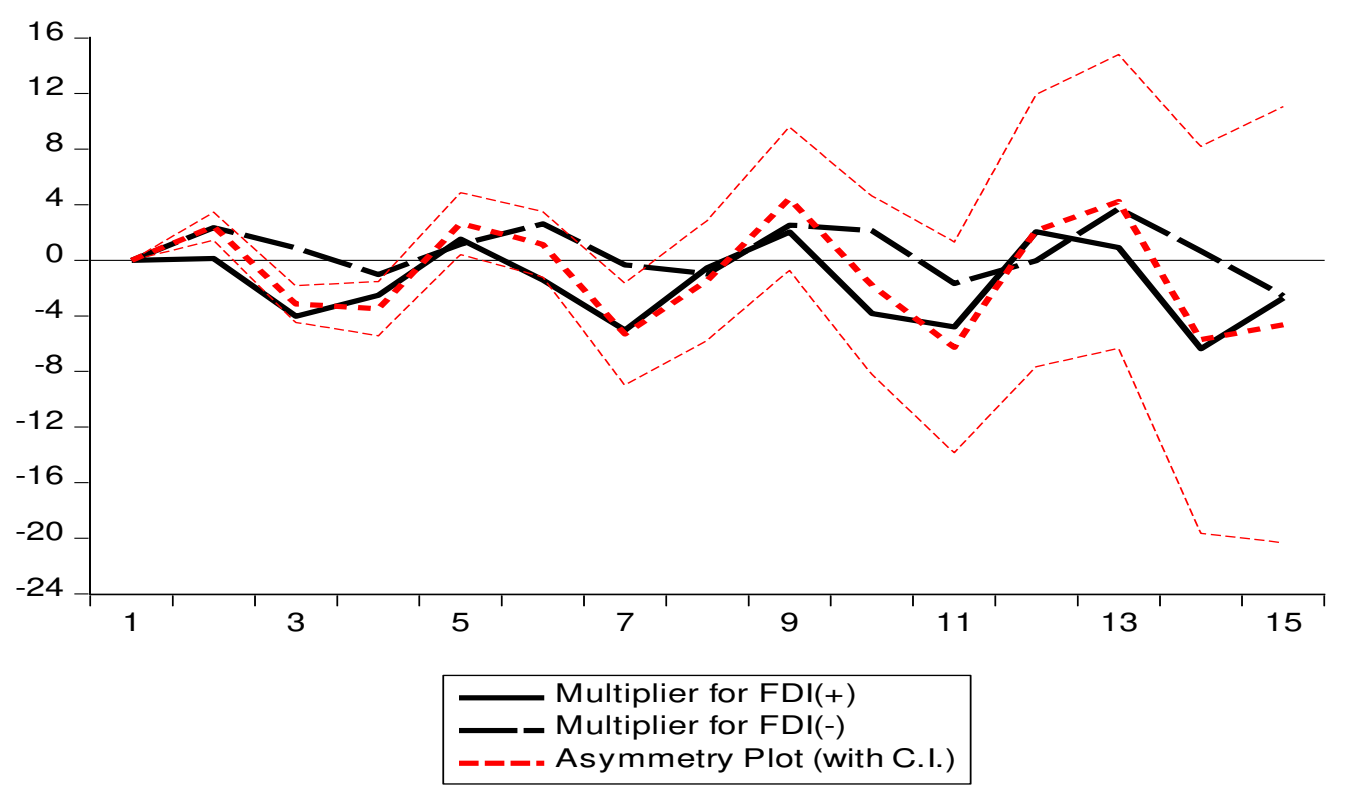




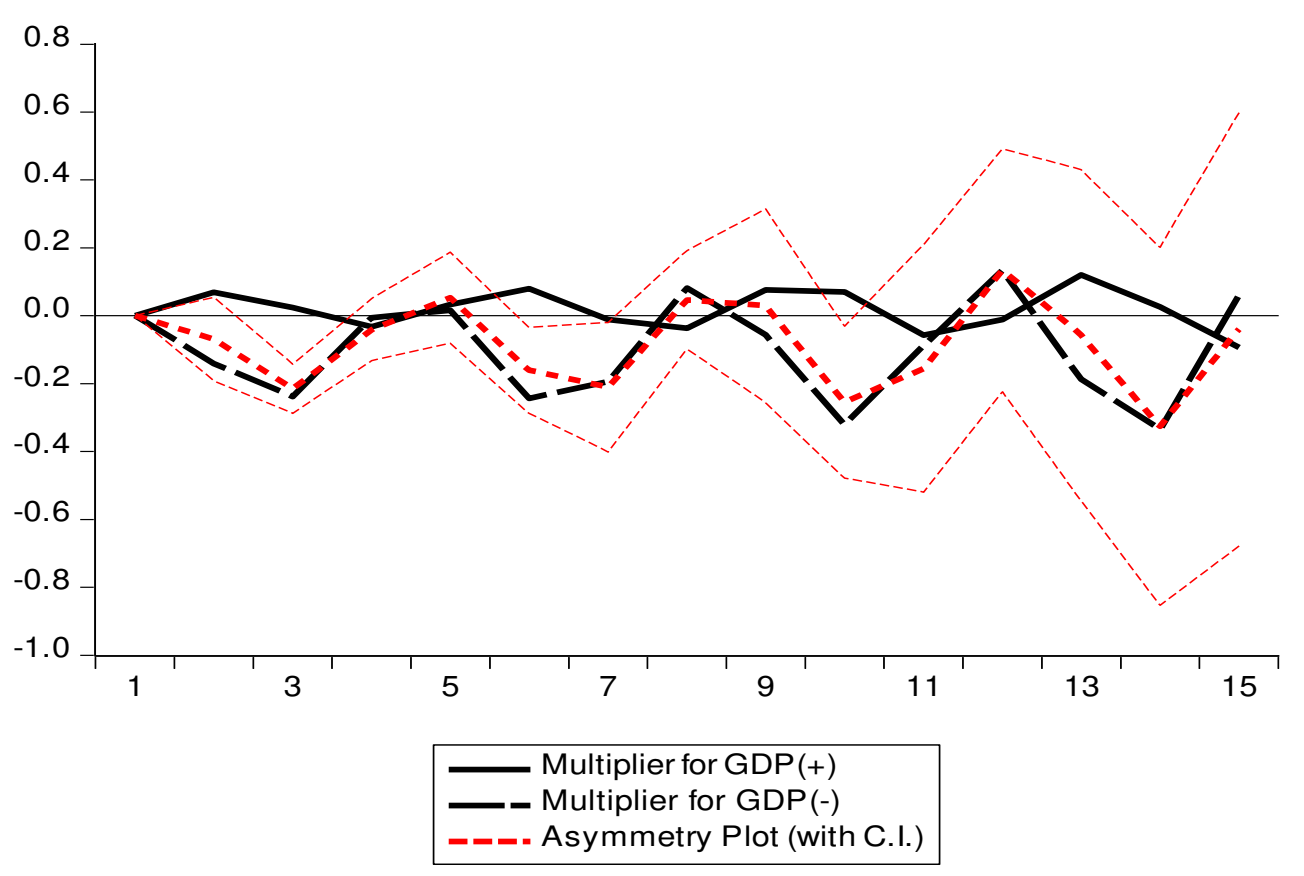

1

2

3

Source: Author's calculation using Eviews 12.

The shocks in CI, GDP, and FDI after a positive change in CI, GDP, and FDI are represented by the solid black line in figure 3. The shock in CI, GDP, and FDI after a negative shift in CI, GDP, and FDI is captured by the black short dashed line. The asymmetry curve, which depicts the difference between positive and negative changes in CI, GDP, and FDI, with its accompanying 95 percent confidence interval for statistical inferences, is represented by the red short dashed line. The zero lines are inside the upper and lower bands of the 95 percent confidence interval in Fig. 4 (a, b, and c), indicating that the asymmetric effect of CI, GDP, and FDI is statistically significant at the 5\% level. The insignificant asymmetry curve shows that shocks in CI, GDP, and FDI hurt a short time but then turn positive in the long run, supporting the positive impact of symmetric CI, GDP, and FDI on access to CI, GDP, and FDI.

\section{Policy Implications}

We can infer some policy implications about environmental quality in Oman based on empirical results: Policymakers should work to increase energy efficiency by building a solid infrastructure that allows businesses and individuals to generate renewable energy from fossil fuels. To improve the environment and promote societal change, Oman must upgrade their high-cost/low-efficiency energy technology to produce more efficient and less energy-dependent commodities. To facilitate renewable energy generation, Oman must invest in renewable energy and promote technology transfers. 
More complex rules and standards can help international investors spread environmentally friendly

2 technologies, encouraging domestic polluting companies to embrace such technology in Oman.

3 These findings should serve as a caution to policymakers that lax environmental rules in their

4 country may hasten environmental degradation. Oman should pursue a dual approach of growing

5 energy infrastructure investment while also passing energy conservation measures to promote energy efficiency and minimize waste to cut $\mathrm{CO}_{2}$ emissions and avoid a negative impact on economic growth. More stringent laws requiring the adoption of energy-efficient technologies

8 should reduce $\mathrm{CO}_{2}$ emissions to pursue economic expansion.

\section{Concluding Remarks}

This study examines the symmetric and asymmetric nexus between capital investment, economic growth, foreign direct investment, and $\mathrm{CO}_{2}$ emissions in Oman during 1980- 2019. For this purpose, we applied Pesaran et al. (2001)'s Autoregressive Distributed Lag (ARDL) for linear cointegration and the Nonlinear Autoregressive Distributed Lag (NARDL) model of Shin et al. (2014)'s for nonlinear cointegration between capital investment, economic growth, foreign direct investment, and $\mathrm{CO}_{2}$ emissions. The coefficient of the ECM model is (-0.501), which signifies that $\mathrm{CO}_{2}$ emissions in Oman converged to their long-run equilibrium level by a $50.1 \%$ speed of adjustment each year due to joining FDI, economic growth, and capital investment. The concept of EKC can be tested by comparing long-term and short-term coefficients in assessing the impact of economic growth on $\mathrm{CO} 2$ emissions. The existence of the EKC hypothesis is confirmed if the estimated long-run coefficient of GDP is smaller than the estimated short-run coefficient (Narayan and Narayan 2010). According to the findings of this study, a one percent rise in GDP reduces $\mathrm{CO}_{2}$ emissions by 0.297 percent in the long run, but a one percent rise in GDP increases $\mathrm{CO} 2$ emissions by 0.360 percent in the short term in Oman. This evidence shows that the EKC 24 hypothesis is influential in Oman, but it contradicts Ozturk and Acaravci's investigation (2010). Ozturk and Acaravci, (2010) sample, which covers the years 1968-2005, could be the source of this discrepancy. In recent years, policymakers in Oman have sought alternative energy sources to

27 prevent environmental deterioration and have increased investment in renewable energy projects such as solar and wind energy. Environmental deterioration has also been decreased as a result of increased public awareness and technological advancements.

30 To evaluate the existence and direction of relationships between variables, the Toda-Yamamoto (1995) causality test is used. This test shows that FDI and $\mathrm{CO}_{2}$ emissions have a feedback 
connection in the case of Oman. The scale effect, which states that foreign direct investment increases a country's $\mathrm{CO}_{2}$ emissions by boosting industrial output, can explain the causal relationship between FDI and $\mathrm{CO}_{2}$ emissions (Zarsky 1999). Our results support the pollution haven hypothesis, revealing a causal association between $\mathrm{CO}_{2}$ emissions and FDI in Oman. Countries with low environmental standards attract more FDI as polluting industries choose to invest in these countries to reduce production costs (Ching 2014).

Moreover, there is a two-directional relationship between economic growth and $\mathrm{CO} 2$ emissions, which means that changes in economic growth lead to changes in $\mathrm{CO} 2$ emissions and vice versa. Capital investment and $\mathrm{CO}_{2}$ emission, on the other hand, have a one-way causal relationship. Hence the capital investment growth hypothesis is irrelevant in Oman. Mutafoglu (2012) similarly confirms a directional reason for capital investment in GDP and has concluded that there is no evidence of investment-led growth assumptions in Oman's economy. Furthermore, there are bidirectional causal links between FDI to GDP and capital investment to FDI. There was no evidence of a causal relationship between $\mathrm{CO}_{2}$ and capital investment in Oman or GDP to capital investment. These results are relevant to the studies of (Chandran and Tand, 2013 and Shahbaz, 2015).

The findings of the NARDL model for long-run and short-run estimations are reported in Table 9. Long-run results reported that FDI is a significant for both positive $\left(L_{F D I}^{+}\right)$and negative $\left(L_{F D I}^{-}\right)$ shocks. It shows that FDI will have a positive impact on Oman's CO2 emissions in the long run. The estimated results of long-run Coefficient $\left(\mathrm{L}_{-}\right.$FDI $\left.{ }^{\wedge}+\right)$ and $\left(\mathrm{L}_{-}\right.$FDI $\left.{ }^{\wedge_{-}}\right)$have been found to be 1.52 and 0.73 respectively, showing a $1 \%$ increase in FDI, which has increased $\mathrm{CO} 2$ emissions in Oman by $1.52 \%$. Similarly, a $1 \%$ fall in FDI will reduce $\mathrm{CO}_{2}$ by $0.73 \%$. This demonstrates that Oman's foreign direct investment is $\mathrm{CO}_{2}$ efficient.

Meanwhile, improving living standards needs a higher quality of life and rigorous environmental rules, and FDI brings more advanced technology that minimizes the country's pollution level. These outcomes are reliable with Chima (2007) and Shahbaz (2014). Regarding GDP, the GDP results are important for both positive $\left(L_{G D P}^{+}\right)$and negative $\left(L_{G D P}^{-}\right)$shocks. Estimates are reported as long-run coefficients $\left(\mathrm{L}_{-} \mathrm{GDP}^{\wedge_{+}}\right)$and $\left(\mathrm{L}_{-} \mathrm{GDP}^{\wedge_{-}}\right) 0.02$ and 0.10 , respectively. We therefore conclude that a $1 \%$ increase in GDP increases CO2 emissions by $0.02 \%$.

Similarly, the negative shock of GDP is also significant with a positive sign. As a result, our findings show that negative changes have a more significant impact. GDP and $\mathrm{CO}_{2}$ emissions have 
1 a positive connotation, suggesting that as GDP rises, production upsurges, increased production

2 escalations the demand of labor and per capita income in the country, so does the usage of $\mathrm{CO}_{2}$

3 emission increases. Consequently, GDP is a source to increase $\mathrm{CO}_{2}$ emissions in Oman. These

4 results are consistent with Aqeel et al. (2001) and Shahbaz et al. (2014). In the long run, positive

5 shocks to capital investment have a significant impact on $\mathrm{CO}_{2}$ emission. This is in accordance with

6 recent studies such as Luqman et al. (2019) for Pakistan and Ghazouani (2021) for Tunisia, where

7 they have had a positive impact on co2 emissions from capital formation. On the other hand, capital

8 investment is not a negative blow and has a negative impact on $\mathrm{CO} 2$ emissions ( 0.39 coefficient).

9 In the short term, positive and negative shocks have similar effects as they are disintegrated

10 factors in the long run. On the other hand, the degrees of elasticity differ slightly, but the relations

11 are nearly identical. The ECM reflects the change in disequilibrium inaccuracy over time in the

12 short term. The estimated methodology maps the progressive adjustment towards the new

13 equilibrium after the shocks from the initial equilibrium. The error correction term (ECT) is

14 negative and statistically significant at a level of $1 \%$. According to ECT, roughly $53 \%$ of the path

15 to long-run equilibrium is completed a year following an economic shock.

Authors contribution: IH \& MM conceptualized, write the original draft, conducted the econometric analysis, and analyzed the findings. MSA compiled the literature review and generated the graphical illustrations, reviewed and edited the final draft. AK write the introduction and compiled the literature review and contributed in the methodology section. PKJ Supervise and review the whole work.

21 Availability of data and materials: Data will be made available upon request.

\section{Declarations}

Ethics approval: Not applicable.

25 Consent to participate: Not applicable.

26 Consent for publication: Not applicable.

27 Funding: No funding was received from any source

28 Competing interests: The author declares no competing interests.

\section{References}

Abdouli, M., \& Hammami, S. (2017). Economic growth, FDI inflows and their impact on the environment: an empirical study for the MENA countries. Quality \& Quantity, 51(1), 121-146. Acharyya, J. (2009). FDI, growth and the environment: Evidence from India on CO2 emission during the last two decades. Journal of Economic Development, 34(1), 43. 
Adofu, I. (2010). Accelerating economic growth in Nigeria, the role of foreign direct investment. Current Research Journal of Economic Theory, 2(1), 11-15.

Al Azri, M. S. J. (2016). Foreign Investment in the Sultanate of Oman: Legal Guarantees and Weaknesses in Providing Investment Protection (Doctoral dissertation, University of Leeds).

Alam, M. J., Begum, I. A., Buysse, J., Rahman, S., \& Van Huylenbroeck, G. (2011). Dynamic modeling of a causal relationship between energy consumption, $\mathrm{CO} 2$ emissions and economic growth in India. Renewable and Sustainable Energy Reviews, 15(6), 3243-3251.

Alkhathlan, K., \& Javid, M. (2013). Energy consumption, carbon emissions and economic growth in Saudi Arabia: An aggregate and disaggregate analysis. Energy Policy, 62(1), 1525-1532.

Apergis, N., \& Payne, J. E. (2011). The emissions, energy consumption, and growth nexus: evidence from the commonwealth of independent states. Energy Policy, 38(1), 650-655.

Apergis, N., Katrakilidis, C. P., \& Tabakis, N. M. (2006). Dynamic linkages between FDI inflows and domestic investment: a panel cointegration approach. Atlantic Economic Journal, 34(4), 385394.

Aqeel, A., \& Butt, M. S. (2001). The relationship between energy consumption and economic growth in Pakistan. Asia-Pacific Development Journal, 8(2), 101-110.

Batten, J. A., \& Vo, X. V. (2009). An analysis of the relationship between foreign direct investment and economic growth. Applied Economics, 41(13), 1621-1641.

Belloumi, M. (2014). The relationship between trade, FDI and economic growth in Tunisia: An application of the autoregressive distributed lag model. Economic Systems, 38(2), 269-287.

Brown, R. L., Durbin, J., \& Evans, J. M. (1975). Techniques for testing the constancy of regression relationships over time. Journal of the Royal Statistical Society: Series B (Methodological), 37(2), 149-163.

Chandran, V. G. R., \& Tang, C. F. (2013). The impacts of transport energy consumption, foreign direct investment and income on $\mathrm{CO} 2$ emissions in ASEAN-5 economies. Renewable and Sustainable Energy Reviews, 24(1), 445-453.

Choe, J. I. (2003). Do foreign direct investment and gross domestic investment promote economic growth? Review of Development Economics, 7(1), 44-57.

Fernandes, A. M., \& Paunov, C. (2012). Foreign direct investment in services and manufacturing productivity: Evidence for Chile. Journal of Development Economics, 97(2), 305-321.

Ghazouani, T. (2021). Impact of FDI inflow, crude oil prices, and economic growth on CO2 emission in Tunisia: Symmetric and asymmetric analysis through ARDL and NARDL approach. Environmental Economics, 12(1), 1-13.

Hacker, S., \& Hatemi-J, A. (2012). A bootstrap test for causality with endogenous lag length choice: theory and application in finance. Journal of Economic Studies,39(2),144-160.

Hamid, I., Jena, P. K., \& Mukhopdhyay, D (2020). Should China prefer more foreign direct investment inflows to environmental change. Journal of Public Affairs, e2466.

Haruna Danja, K. (2012). Foreign direct investment and the Nigerian economy. American Journal of Economics, 2(3), 33-40.

Hermes, N., \& Lensink, R. (2003). Foreign direct investment, financial development and economic growth. The Journal of Development Studies, 40(1), 142-163.

Hussein, M., A., and Sid Ahmed, H., M., (2019). The Impact of Foreign Direct Investment on Economic Growth in Oman. Global Journal of Economics and Business, 6(3), 551- 563.

Irandoust, J. E. M. (2001). On the causality between foreign direct investment and output: a comparative study. The International Trade Journal, 15(1), 1-26. 
Keller, W., \& Levinson, A. (2000). Environmental regulations and FDI inflows to U.S. states (No. gueconwpa 00-00-06).

Kohler, M. (2005). CO2 emissions, energy consumption, income and foreign trade: A South African perspective. Energy Policy, 63, 1042-1050.

Lau, L. S., Choong, C. K., \& Eng, Y. K. (2014). Investigation of the environmental Kuznets curve for carbon emissions in Malaysia: do foreign direct investment and trade matter? Energy Policy, 68(1), 490-497.

Lee, J. W. (2013). The contribution of foreign direct investment to clean energy use, carbon emissions and economic growth. Energy Policy, 55(1), 483-489.

Li, G., Zakari, A., \& Tawiah, V. (2020). Does environmental diplomacy reduce CO2 emissions? A panel group means analysis, Science of The Total Environment, 722, 137790.

Luqman, M., Ahmad, N., \& Bakhsh, K. (2019). Nuclear energy, renewable energy and economic growth in Pakistan: Evidence from nonlinear autoregressive distributed lag model. Renewable Energy, 139(1), 1299-1309.

Malik, A., \& Lan, J. (2016). The role of outsourcing in driving global carbon emissions. Economic Systems Research, 28(2), 168-182.

Mallampally, P., \& Sauvant, K. P. (1999). Foreign direct investment in developing countries. Finance and Development, 36(1), 34-37.

Martínez-Zarzoso, I., \& Bengochea-Morancho, A. (2004). Pooled mean group estimation of an environmental Kuznets curve for CO2. Economics Letters, 82(1), 121-126.

Mutafoglu, T. H. (2012). Foreign direct investment, pollution, and economic growth: Evidence from Turkey. Journal of Developing Societies, 28(3), 281-297.

Ndikumana, L., \& Verick, S. (2008). The linkages between FDI and domestic investment: Unravelling the developmental impact of foreign investment in Sub-Saharan Africa. Development Policy Review, 26(6), 713-726.

Neequaye, N. A., \& Oladi, R. (2015). Environment, growth, and FDI revisited. International Review of Economics \& Finance, 39(2), 47-56.

Ozturk, I., \& Acaravci, A. (2010). CO2 emissions, energy consumption and economic growth in Turkey. Renewable and Sustainable Energy Reviews, 14(9), 3220-3225.

Pao, H. T., \& Tsai, C. M. (2011). Modeling and forecasting the CO2 emissions, energy consumption, and economic growth in Brazil. Energy, 36(5), 2450-2458.

Pesaran, M. H. (1997). The role of economic theory in modeling the long run. The Economic Journal, 107(440), 178-191.

Pesaran, M. H., Shin, Y., \& Smith, R. J. (2001). Bounds testing approaches to the analysis of level relationships. Journal of Applied Econometrics, 16(3), 289-326.

Rafindadi, A. A., Muye, I. M., \& Kaita, R. A. (2018). The effects of FDI and energy consumption on environmental pollution in predominantly resource-based economies of the GCC. Sustainable Energy Technologies and Assessments, 25(3), 126-137.

Reiter, S. L., \& Steensma, H. K. (2010). Human development and foreign direct investment in developing countries: the influence of FDI policy and corruption. World Development, 38(12), 1678-1691.

Shahbaz, M., Hye, Q. M. A., Tiwari, A. K., \& Leitão, N. C. (2013). Economic growth, energy consumption, financial development, international trade and $\mathrm{CO} 2$ emissions in Indonesia. Renewable and Sustainable Energy Reviews, 25(1), 109-121. 
Shahbaz, M., Van Hoang, T. H., Mahalik, M. K., \& Roubaud, D. (2017). Energy consumption, financial development and economic growth in India: New evidence from a nonlinear and asymmetric analysis. Energy Economics, 63(2), 199-212.

Shan, Y., Guan, D., Liu, J., Ma, Z., Liu, Z., Liu, J., \& Zhang, Q. (2017). Methodology and applications of city-level CO2 emission accounts in China. Journal of Cleaner Production, 161(3), 1215-1225.

Shin, Y., Yu, B., \& Greenwood-Nimmo, M. (2014). Modeling asymmetric cointegration and dynamic multipliers in a nonlinear ARDL framework. In Festschrift in Honor of Peter Schmidt (pp. 281-314). Springer, New York, NY.

10 Stern, D. I. (2015). The role of energy in economic growth. International Energy and Poverty, 3547.

Stretesky, P. B., \& Lynch, M. J. (2009). A cross-national study of the association between per capita carbon dioxide emissions and exports to the United States. Social Science Research, 38(1), 239-250.

Toda, H. Y., \& Yamamoto, T. (1995). Statistical inference in vector autoregressions with possibly integrated processes. Journal of Econometrics, 66(1-2), 225-250.

Wu, J., Zhu, Q., \& Liang, L. (2016). CO2 emissions and energy intensity reduction allocation over provincial industrial sectors in China. Applied Energy, 166(4), 282-291.

Xing, Y., \& Kolstad, C. D. (2002). Do lax environmental regulations attract foreign investment? Environmental and Resource Economics, 21(1), 1-22.

Zhang, C., \& Zhou, X. (2016). Does foreign direct investment lead to lower CO2 emissions? Evidence from a regional analysis in China. Renewable and Sustainable Energy Reviews, 58(2), 943-951.

Zhao, C., \& Du, J. (2007). Causality between FDI and economic growth in China. Chinese Economy, 40(6), 68-82.

Zivot, E., \& Andrews, D. W. K. (2002). Further evidence on the great crash, the oil-price shock, and the unit-root hypothesis. Journal of Business \& Economic Statistics, 20(1), 25-44. 